\title{
Özel/Üstün Yetenekli Ortaokula Devam Eden Ön Ergenler İçin Sosyal Beceri Ölçeğinin Geliştirilmesi ve Psikometrik Özelliklerinin İncelenmesi*
}

\author{
Zeynep KARATAŞ ${ }^{1}$ Özlem TAGAY ${ }^{2}$
}

• Geliş Tarihi: 01.06.2020 • Kabul Tarihi: 01.10.2020 • Çevrimiçi Yayın Tarihi: 13.10.2020

\section{$\ddot{\mathbf{O} z}$}

Bu çalışmada ön ergenlik döneminde olan ve ortaokula devam eden özel/üstün yetenekli öğrenciler için sosyal beceri ölçeğinin geliştirilmesi amaçlanmıştır. Türkiye genelinde Çeşitli Bilim ve Sanat Merkezleri'nde eğitim gören özel/üstün yetenekli 626 gönüllü ortaokul öğrencisi ile çalışma yürütülmüş olup araştırmada üç farklı çalışma grubu kullanılmıştır. İlk grup pilot uygulamanın gerçekleştirildiği 20 öğrenciden oluşmaktadır. İkinci çalışma grubu geçerlik ve güvenirlik çalışmalarının yapıldığı 406 öğrenciden ve doğrulayıcı faktör analizinin gerçekleştirildiği üçüncü çalışma grubu ise 200 öğrenciden oluşmaktadır. Ölçek geliştirme çalışmasında; geçerlik çalışmalarında açımlayıcı ve doğrulayıcı faktör analizi ile benzer ölçekler geçerliğinden faydalanılmıştır. Güvenirlik çalışmasında ise Cronbach Alpha iç tutarlık katsayısı, madde toplam puan korelasyonu ve test yarılama teknikleri kullanılmıştır. Çalışmanın bulguları incelendiğinde yapılan geçerlik ve güvenirlik analizleri sonucunda 37 maddelik özel/üstün yetenekli ortaokul öğrencileri için geliştirilen sosyal beceri ölçeğinin, özel/üstün yetenekli ortaokul öğrencilerinde kullanılabilecek geçerli ve güvenilir bir ölçek olduğu görülmüştür.

Anahtar sözcükler: Özel/üstün yetenek, ön ergen, ortaokul öğrencisi, sosyal beceri

\section{Atıf:}

Karataş, Z. ve Tagay, Ö. (2021). Özel/üstün yetenekli ortaokula devam eden ön ergenler için sosyal beceri ölçeğinin geliştirilmesi ve psikometrik özelliklerinin incelenmesi. Pamukkale Üniversitesi Eğitim Fakültesi Dergisi, 51, 367-392.doi:10.9779/pauefd.746428.

\footnotetext{
* Bu makale Burdur MAKÜ BAP Komisyonu tarafından desteklenen 0355-NAP-16 numaralı projeden üretilmiştir.

1 Prof. Dr. Burdur MAKÜ, Eğitim Fak. Eğitim Bil. Böl., zeynepkaratas1972@hotmail.com, http://orcid.org/ 0000-0002-4532-6827

2 Doç. Dr. Burdur MAKÜ, Eğitim Fak. Eğitim Bil. Böl., ozlemtagay@ gmail.com, http://orcid.org/0000-0002-9821-5960
} 


\section{Giriș}

Yetenek sözcügü herhangi bir şeyi yapabilme becerisi anlamına gelir ve dilimizde tek bir şeye işaret etmeyen geniş ve kapsayıcı bir sözcük olarak kullanılır (Bilgiç, Taştan, Kurukaya, Kaya, Avanoğlu ve Topal, 2013). Yetenek sözcüğünün zaman zaman üstün zekalı yerine kullanıldığı görülse de üstün zekalı ve özel yetenekli öğrenciler konusunda geliştirilen tanımlarda çeşitlilik olduğu gözlenirken çok az fikir birliği olduğu bilinmektedir. 1990'ların ortasında “yetenekli” terimi “üstün zekalı” ifadesinin yerine kullanılmıştır. Hatta bu dönemde öğrencileri yetenekli ve üstün yetenekli olarak ayırdıkları göze çarpmaktadır (Freeman, 2001). Gagne (1991) üstün zekalı kavramını insan yeteneğindeki ortalamanın üzerinde yetkinlik olarak tanımlarken; özel yetenek kavramını ise bireyin belirli bir alanda ortalamanın üzerindeki performansı olarak tanımlamıştır. Eyre (1999) üstün yetenek için daha basit bir tanım kullanmış ve üstün yetenekliliği akran grubundan önemli ölçüde ileri seviyeye ulaşan ve başarma becerisine sahip olan çocuklar olarak tanımlamıştır. MEB (2018) ise özel yeteneği; kendi yaşıtlarına nazaran daha hızlı öğrenen, sanat, liderlik ve yaratıcılıkta önde olan, özel akademik bir yeteneği olan, soyut kavramları anlayabilen, ilgi alanlarında bağımsız hareket etmekten hoşlanan ve yüksek düzeyde performans gösteren bireyler" şeklinde ifade etmiştir.

Okullar normal gelişim gösteren, gelişim geriliği bulunan ve özel/üstün yetenekli öğrencilerin bir arada okuduğu kurumlardır. Bu kurumlarda farklı gelişim özelliği gösteren bu öğrencilerin etkili bir şekilde gelişimlerini desteklemek ve onlara rehberlikte bulunmak en önemli hedeflerden birisidir. Böylece bireyin hem okulda hem de sosyal yaşamda bazı beceriler sergileyebilmelerine yardımcı olmak hedeflenmektedir.

Sosyal yaşam bireylerin içinde bulunduğu durum, ortam ve şartlara uyum sağlamasını ve diğerleri ile ilişkilerinde sağlıklı ilişkiler kurmasını beraberinde getirir. Kişilerin sosyal uyumunu geliştirebilecek ve ortaya koyacak temel becerilerden bir tanesi ise sosyal beceridir. Cartledge ve Milburn (1983) sosyal beceri konusunda dört ortak ögeden söz etmiştir. Bunlar; (1) Diğerlerinin olumlu tepki vermesini sağlayacak, olumsuz gelebilecek tepkileri önleyecek ve diğerleriyle etkileşimi sağlayabilecek sosyal olarak kabul edilmiş öğrenilmiş davranışlar; (2) Çevreyi etkileyen amaca yönelik davranışlar; (3) Duruma özgü ve duruma göre değişen davranışlar; (4) Bilişsel ve duyuşsal öğeler içeren gözlenebilir ya da gözlenemeyen davranışlardır (Akt. Yüksel, 1999). Ayrıca Yüksel (1999), ifade edilen bu öğrenebilir davranışların sosyal bilgiyi alma, çözümleme, anlama ve uygun tepkide bulunmayı kapsadığını belirtmiştir. Kişi bu davranışları göstererek çeşitli ortamlarda 
diğerleri tarafından pekiştirilir. Ayrıca bu pekiştirmelerle bu davranışları sürdürmeye devam ederler. Davranış şeklinde ortaya çıkan sosyal beceriler aynı zamanda kişilerarası bir öneme de sahiptir ve çevredeki kişiler tarafından hoşlanılan ve takdir edilen davranışlardır (Bacanlı, 1999).

Sosyal beceriler bir çocuğun akademik yeteneğini ortaya çıkarmasında ve kullanabilmesinde büyük bir öneme sahiptir ve sınıf bu sosyal becerilerin geliştirilmesi için bir eğitim alanı ve bu becerilerin kullanıldı̆̆ı ve ortaya koyulduğu bir arenadır (Steedly, Schwartz, Levin ve Luke, 2008). Öğrencilere eğitim süreci içerisinde sosyal beceriler kazandırılmadığı zaman okul başarısında düşmeler, kişiler arası ilişkilerde yetersizlikler ve uyum sorunları ortaya çıkabilmektedir (Akkök, 1999). Ayrıca sosyal becerilerin eksikliği durumunda bireylerin sosyal ve duyuşsal alanlarda ilişki kurmada bu ilişkileri sürdürmede ve karşılaştıkları güçlüklerle başa çıkmada sorunlar yaşayabilecekleri de belirtilmektedir (Şahin, 2001).

Sosyal becerilerdeki sorunlar yaşamın her aşamasında özellikle arkadaşları ile birlikteyken oyunda, okulda ve evde bireyi olumsuz etkileyecektir. Çalışmalar sosyal becerilerdeki yetersizliklerin bireyde ortaya çıkan öğrenme sorunları için önemli bir neden olduğunu ortaya koymaktadır. Bu çalışmalarda sosyal durumları anlayamama ya da yanlış okuma, diğerlerine, çevreye ya da doğaya duyarlı davranmama ve sosyal dışlanma ile ilgili üzüntü duymanın öğrenmede oluşabilecek yetersizlik için önemli sosyal sorunlar olduğunu belirtmişlerdir (Bryan, 1991; Akt. Seven, 2008; Samancı ve Diş, 2014). Sosyal becerinin kişiler arası ilişkilerle, benlik algısı ile akran ilişkileri ile iletişim becerileri ve akademik başarı ile ilişkili olduğu belirtilmiştir (Elksnin ve Elksnin, 1995). Ayrıca olumlu sosyal becerilerin sağlıklı sosyal gelişim için önemli olduğu vurgulanırken, olumlu sosyal becerileri olan çocukların benlik saygısı düzeyinin yüksek olacağı okul ve okul dışındaki akranları ile olumlu ilişkiler kuracağı belirtilmiştir. (Tagay, Baydan ve Voltan-Acar, 2010; Uysal ve Kalkan, 2015) Bunların yanı sıra çocukluktaki olumlu sosyal becerilerin gençlik ve yetişkinlik yıllarındaki sosyal becerilerle de ilişkili olduğu vurgulanmıştır (Tawana ve Moorc, 2011).

Özel/ üstün yetenekli öğrencilerin temel sosyal ihtiyaçları diğer öğrencilerden farklı değildir ancak bu öğrencilerin ihtiyaçları içsel ve dışsal nedenlerden dolayı farklılık gösterebilir. İçsel özelliklerle kastedilen bu öğrencilerin duyarlılık ve öz-eleştiri gibi farklı kişisel özelliklere sahip olmalarıdır. Dışsal nedenler ise diğerleri ile kurdukları etkileşimlerinde daha uyumsuz olarak algılanmaları ve başa çıkma konusunda sıkıntı yaşayabilmeleridir. Özel/üstün yetenekli olmanın doğası gereği bu öğrencilerin farklı 
yaklaşımları içeren eğitimlere olan ihtiyacı artmaktadır. Bu öğrencilerin yaşadıkları içsel ve dışsal zorluklar dikkate alınarak ihtiyaçlarına yönelik eğitim programları geliştirmek ve uygulamak gerekmektedir (Cross ve Cross, 2015). Özel/üstün yetenekli öğrencilerin fiziksel, bilişsel, sosyal ve duygusal gelişimleri birbiriyle uyuşmayabilmektedir. Örneğin öğrencinin bilişsel gelişimi çok ilerde olduğu halde fiziksel ve sosyal-duygusal gelişimi çok ilerlememiş olabilmekte ve çevresinin kendisinden çok fazla beklentisi olmasına rağmen kendisi bu beklentiyi yerine getiremediği için zorlanmaktadır. Bu nedenle bu çocuklar yaşadıkları olumsuz durumlardan dolayı daha çok hayal kırıklı̆ğ ve öfke yaşayabilmektedirler. Hatta bu çocukların sosyal duygusal gelişimlerinin bazı durumlarda yaşıtlarının gerisinde kaldığı ve potansiyelleri ile yeteneklerini ortaya koyma noktasında sorun yaşadıkları görülmektedir (Silverman, 2002).

Özel/üstün yetenekli çocuklardan bazılarının arkadaşları tarafından kabul görmek adına ilgilerini ve özel yeteneklerini gizlemeye çalıştıkları ve bu sayede yalnız kalmamaya çalıştıkları gözlenmektedir. Bazıları ise farklılıkları nedeniyle dışlanmakta ve arkadaş bulmakta güçlük çekmektedir. Ayrıca özel/üstün yetenekli öğrenciler mükemmeliyetçi özellikleri nedeniyle akranları tarafindan yanlış algılanmakta ve sorun yaşamaktadırlar (Akkan, 2012). Pek çok araştırmacı özel/üstün yetenekli öğrencilerin özellikle erken ergenlik döneminde duygusal ve sosyal sorunlara sahip olma konusunda daha riskli olduklarını vurgulamaktadır. Özel/üstün yetenekli öğrenciler kişilerarası çatışmalara daha duyarlıdır ve yetenekleri nedeniyle akranlarına oranla daha yüksek düzeyde strese maruz kalırlar. Bu nedenlerle daha endişeli ve daha depresif olabilmektedirler (Hallahan ve Kauffman, 2003).

Alan yazın incelendiğinde normal gelişim gösteren öğrenciler üzerinde sınırlı sayıda da olsa sosyal beceri ölçek çalışmalar olduğu görülmektedir. Bu ölçek çalışmalarının normal gelişim gösteren okul öncesi (Anme, Shinohara, Sugisawa, Tanaka, Watanabe, ve Hoshino, 2013; Avcığlu, 2007; Gresham ve Elliot, 2008; Merrell, 2002; Ömeroğlu, Büyüköztürk, Aydoğan, Çakan, Kılıç Çakmak, Özyürek, Gültekin Akduman, Günindi, Kutlu, Çoban, Yurt, Koğar, ve Karayol, 2014) ilkokul (Gresham ve Elliot, 1990; Karataş, Sağ ve Arslan, 2015) ortaokul ve ortaöğretim öğrencileri (Gresham ve Elliot, 2008; Matson, Rotatori ve Helsel, 1983; Riggio, 1986) üzerinde olduğu görülmektedir. Bu geliştirilmiş olan ölçeklerden sadece bir ölçeğin hem normal gelişim gösteren hem de kaynaştırma öğrencilerinde kullanılabileceği belirtilmiştir (Gresham ve Elliot, 1990). Ancak ilgili yazında özel/üstün yetenekli öğrencilerin sosyal becerileri üzerinde geliştirilmiş herhangi bir ölçeğe rastlanmamıştır. Alan yazında özel/üstün yetenekli öğrencilerde kullanılabilecek bir sosyal 
beceri ölçme aracının bulunmadığı görüldüğünden bu çalışma bu hali ile bir ilk olacak ve ilgili alan yazında bilgi birikimine temel oluşturacaktır. Bu doğrultuda bu çalışmanın amacı Türkiye örnekleminde kullanılabilecek özel/üstün yetenekli ön ergenlik döneminde bulunan ortaokul öğrencileri için sosyal beceri ölçeği geliştirmek ve psikometrik özelliklerini incelemektir.

\section{Yöntem}

\section{Araştırmanın Modeli}

Araştırmada betimsel tarama yöntemi kullanılmıştır. Betimsel yöntem var olan yapıyı herhangi bir işlem yapmadan yansıtan, bir grubun belirli özelliklerini belirlemek için verilerin toplanmasını amaçlayan çalışmalardır (Büyüköztürk, Kılıç-Çakmak, Akgün, Karadeniz ve Demirel, 2016).

\section{Çalışma Grubu}

Milli Eğitim Bakanlığından gerekli izinler alındıktan sonra 13.05.2020 tarihinde Burdur Mehmet Akif Ersoy Üniversitesi Girişimsel Olmayan Klinik Araştırmalar Etik Kurulundan etik kurul onayı (GO 2020/130) alınmıştır. Çalışmaya katılmaya istekli Bilim ve Sanat Merkezleri (BİLSEM) ile bu merkezlerde çalışmaya katılmaya gönüllü olan özel/üstün tanısı almış ortaokul öğrencilerinden üç ayrı grupta yer alan toplam 626 özel/üstün yetenekli öğrenciye ait bilgiler aşağıda verilmiştir.

Birinci çalışma grubu: İlk grupta yer alan 20 (12 k1z, 8 erkek) öğrenci ile "özel/üstün yetenekli ortaokul öğrencilerinde kullanılabilecek sosyal beceri ölçeği” nin madde havuzunu oluşturmak amaciyla odak grup görüşmeleri ve madde havuzundaki maddelerin anlaşılırlığını kontrol etmek için pilot uygulama yapılmıştır.

İkinci çalışma grubu: Çeşitli BİLSEM'e devam eden 406 özel/üstün ortaokul öğrencisinden oluşan ikinci çalışma grubunun verileri ile ölçeğin açımlayıcı faktör analizi ve güvenirlik analizleri yapılmıştır.

İkinci çalışma grubu katılımcılarının demografik özellikleri Tablo 1'de gösterilmiştir.

Tablo 1'de görüldüğü gibi ölçek uygulamasının açımlayıcı faktör analizi ve güvenirlik çalışmaları için oluşturulan 406 öğrenciden 178'i kız, 228'i erkektir. Bu öğrencilerden 143'ü beşinci sınıf, 72'si altıncı sınıf, 122'si yedinci sınıf ve 69'u sekizinci sınıf öğrencisidir. Öğrencilerin 15 farklı BİLSEM'de eğitim gördükleri de görülmektedir. 
Tablo 1. İkinci Çalışma Grubunun Katılımcılarının Demografik Özellikleri

\begin{tabular}{lll}
\hline & $\mathrm{f}$ & $\%$ \\
\hline Kız & 178 & 43.8 \\
Erkek & 228 & 56.2 \\
Toplam & 406 & 100 \\
& & \\
5. Sınıf & 143 & 35.2 \\
6. Sınıf & 72 & 17.7 \\
7. Sınıf & 122 & 30 \\
8. Sınıf & 69 & 17 \\
Toplam & 406 & 100 \\
& & \\
Antalya BİLSEM & 49 & 12 \\
Selçuklu BİLSEM & 16 & 3.9 \\
Denizli BİLSEM & 54 & 13.3 \\
Burdur BİLSEM & 49 & 12.1 \\
Düzce BİLSEM & 17 & 4.2 \\
Bursa BİLSEM & 34 & 8.4 \\
Konya BİLSEM & 32 & 7.9 \\
Isparta BİLSEM & 37 & 9.1 \\
Tarsus BİLSEM & 18 & 4.4 \\
Kahramanmaraş BİLSEM & 19 & 4.7 \\
Uşak BİLSEM & 27 & 6.7 \\
Gaziantep BİLSEM & 23 & 5.7 \\
Muğla BİLSEM & 4 & 1.0 \\
Afyonkarahisar BíLSEM & 14 & 3.4 \\
İzmir BİLSEM & 7 & 1.7 \\
Toplam & 406 & 100 \\
\hline & & \\
& & \\
& & \\
& &
\end{tabular}

Ü̧̧ӥncü çalışma grubu: Çeşitli BİLSEM'e devam eden 200 özel/üstün ortaokul öğrencisinden oluşan üçüncü çalışma grubunun verileri doğrulayıcı faktör analizi için kullanılmıştır. Grubun katılımcılarının demografik özellikleri Tablo 2'de gösterilmiştir. 
Tablo 2. Üçüncü Çalışma Grubunun Katılımcılarının Demografik Özellikleri

\begin{tabular}{|c|c|c|}
\hline & $\mathrm{f}$ & $\%$ \\
\hline $\mathrm{K} 1 \mathrm{z}$ & 71 & 35.5 \\
\hline Erkek & 129 & 64.5 \\
\hline Toplam & 200 & 200 \\
\hline 5. Sinif & 32 & 16 \\
\hline 6. Sinif & 48 & 24 \\
\hline 7. Sinif & 66 & 33 \\
\hline 8. Sinif & 54 & 27 \\
\hline \multicolumn{3}{|l|}{ Toplam } \\
\hline Antalya BİLSEM & 31 & 15.5 \\
\hline Selçuklu BİLSEM & 11 & 5.5 \\
\hline Denizli BİLSEM & 26 & 13 \\
\hline Burdur BİLSEM & 21 & 10.5 \\
\hline Düzce BİLSEM & 6 & 3 \\
\hline Bursa BILLSEM & 15 & 7.5 \\
\hline Konya Meram BİLSEM & 14 & 7 \\
\hline Isparta BİLSEM & 20 & 10 \\
\hline Tarsus BİLSEM & 5 & 2.5 \\
\hline Kahramanmaraş BİLSEM & 12 & 6 \\
\hline Uşak BİLSEM & 13 & 6.5 \\
\hline Gaziantep BİLSEM & 7 & 3.5 \\
\hline Muğla BİLSEM & 2 & 1.0 \\
\hline Afyonkarahisar BİLSEM & 10 & 5 \\
\hline İzmir BİLSEM & 2 & 1 \\
\hline Toplam & 200 & 100 \\
\hline
\end{tabular}

Tablo 2'de görüldüğü gibi ölçek uygulamasının doğrulayıcı faktör analizi çalışmaları için oluşturulan 200 öğrencinin 71'i kız 129'u erkektir. Bu öğrencilerden 32'si beşinci sınıf, 48'si altıncı sınıf, 66'sı yedinci sınıf ve 54'ü sekizinci sınıf öğrencisidir. Ayrıca öğrencilerin 15 farklı BİLSEM'de eğitim gördüğü görülmektedir. 


\section{Ölçek Madde Havuzunun Oluşturulma Aşamaları}

Burdur Merkezdeki Alparslan Alican BİLSEM'de özel/üstün yetenekli tanısı almış ortaokul öğrencilerinden 20 öğrenciye sosyal beceri özelliklerini anlatan bir metin yazmaları istenmiştir. Bu metinleri "Sosyal beceriyi nasıl tanımlarsınız?”, “Sosyal becerisi yüksek bireylerin gösterdiği özellikler nelerdir, bu bireyler hangi sosyal davranışları daha kolay yapabilmektedir?" sorularına cevap verecek şekilde yazmaları istenmiştir. Bu metinlerden, çeşitli sosyal beceri ölçeklerindeki ifadelerden ve kuramsal çerçeve ile alan yazın da dikkate alınarak 62 sosyal beceri ifadesi oluşturulmuştur. Bu ifadelerin sosyal beceri ifadesi olup olmadığ uzmanının (Üniversitelerin Rehberlik ve Psikolojik Danışma bölümünde görev yapan üç öğretim üyesi ile Özel Eğitim Bölümlerinde görev yapan iki öğretim üyesi) görüşü alınarak ölçeğin deneme formu hazırlanmıştır. Daha sonra deneme ölçeğindeki ifadelerin anlaşılır olup olmadığını kontrol etmek için aynı öğrencilerle pilot uygulama yapılmış ve anlaşılmayan maddelerin belirtilmesi istenmiştir. $\mathrm{Bu}$ maddelerin incelenmesi ve anlaşı1mayan ifadelerin de düzenlenmesi ile ölçeğin deneme formuna son şekli verilmiştir. $\mathrm{Bu}$ formda 62 doğrudan puanlanan ifade bulunmaktadır.

\section{İşlem}

$\mathrm{Bu}$ çalışmada ön ergenlik döneminde bulunan özel/üstün yetenekli ortaokul öğrencilerinin sosyal becerileri için hazırlanan 62 maddelik 4'lü Likert tipi ölçeğin deneme formu, MEB'den alınan izin doğrultusunda, Türkiye genelinde uygulamaya katılmaya gönüllü 15 BİLSEM ve o BİLSEM'lerde eğitime devam eden gönüllü ortaokul öğrencilerine uygulanmış ve uygulama sonucunda elde edilen verilere geçerlik ve güvenirlik analizleri yapılmıştır. Analiz sonucunda 37 maddelik sekiz faktörlü asıl ölçek formu ortaya çıkarılmıştır.

\section{Veri Toplama Araçları}

\section{KA-Si ergenler için empatik ĕgilim ölçeği}

Benzer ölçekler geçerliği için kullanılan KA-Sİ ergenler için empatik eğilim ölçeği Kaya ve Siyez (2010) tarafından geliştirilmiştir. Altı-Onikinci sınıflara devam eden öğrencilere uygulanabilen 17 maddelik iki boyutlu bir ölçektir. Bilişsel empati boyutunda 7 madde, duygusal empati boyutunda 10 madde bulunmaktadır. Açımlayıcı faktör analizi sonucunda ölçeğin toplam varyansın \%43.588'ini açıkladığı saptanmıştır. Ölçek iki faktörlü bir yapıda olup, duygusal empati alt boyutu toplam varyansın \% 33.234'ünü, bilişsel empati alt boyutu ise \%10.354'ünü açıklamaktadır. Doğrulayıcı faktör analizi sonucu ise ölçeğin iki faktörlü 
yapısının doğrulandığını ve ölçeğin iyi uyum verdiğini göstermektedir. Güvenirlik analizinde Cronbach Alpha iç tutarlık katsayısı, ölçeğin tümü için .87, .alt boyutlar için sırasıyla .82 ve. 82 olarak saptanmıştır. Ölçeğin tümü için test-tekrar test güvenirlik katsayısı .75 , alt boyutlar için sırasıyla .73 ve .69 olarak bulunmuştur (Kaya ve Siyez, 2010). Bu çalışmanın verilerinde Cronbach Alpha değeri alt ölçeklerin sırası ile .81 ve .83 olarak bulunmuştur.

\section{Verilerin Çözümlenmesi}

$\mathrm{Bu}$ çalışmada özel/üstün yetenekli ortaokul öğrencileri için geliştirilen sosyal beceri ölçeğinin geçerliği kapsamında açımlayıcı ve doğrulayıcı faktör analizi yapılmıştır. Açımlayıcı faktör analizine başlamadan önce veri yapısının faktörleşmeye uygun olup olmadığına KMO ve Barlett's küresellik test sonuçları ile bakılmıştır. Analiz sonucunda veri yapısının faktörleşmeye uygun olduğu sonucuna varılmıştır. Daha sonra açımlayıcı faktör analizi uygulanmıştır. Ölçeğin güvenirliğini belirlemek için ise Cronbach Alpha iç tutarlık katsayısı, iki yarı test güvenirliği ve test tekrar test analizleri uygulanmıştır. Ölçeğin faktör yapısının kuramsal olarak doğrulanıp doğrulanmadığını ortaya koyabilmek için doğrulayıcı faktör analizi yapılmıştır.

\section{Bulgular}

\section{Özel/Üstün Yetenekli Ön Ergenlik Döneminde Olan Ortaokul Öğrencileri İçin Sosyal Beceri Ölçeği Geliştirme Çalışmasının Bulguları}

Bu bölümde "özel/üstün yetenekli ön ergenlik döneminde olan ortaokul öğrencileri için sosyal beceri ölçeği” geçerlik ve güvenirlik çalışmalarına ait bulgulara yer verilmiştir.

\section{Yapı Geçerliğine İlişkin Bulgular}

\section{Açımlayıcı Faktör Analizi}

Ölçeğin yap1 geçerliği için açımlayıcı faktör analizi yapılmıştır. Analizler öncesinde verilerin faktör analizine uygunluğunu incelemek amacıyla, veri setinde uç değerler olup olmadığı z tablo değerleri ile incelenmiş ve 15 veri, veri setinden çıkarılmıştır. Çok değişkenli uç değerler için Mahalanobis uzaklığı (Tabachnick ve Fidell, 2007) incelenmiş ve 1'in üzerinde değer bulunmamıştır. Böylece, açımlayıcı faktör analizi için 406 veri kullanılmıştır.

Örneklemin faktör analizine uygunluğu için hesaplanan Kaiser-Meyer-Olkin (KMO) katsayısı .93 olarak çıkmıştır. Barlet alan testi değeri $\chi^{2}: 10635.941, \mathrm{p}<.05$ olarak anlamlı çıkmıştır. Ayrıca analizi yapılan maddelerin ortak faktör varyansının (Communalities) .416- 
.731 arasında değiştiği görülmüştür. KMO değerinin, .60 değerinden büyük çıkmas1 verilerin faktör analizi için uygun olduğunu göstermektedir (Büyüköztürk, 2012). Veri setinin açımlayıcı faktör analizine uygunluğu sağlandıktan sonra faktör analizi işlemi gerçekleştirilmiştir.

İlk deneme formu olan 62 maddelik özel/üstün yetenekli ön ergenlik döneminde olan ortaokul öğrencileri için sosyal beceri ölçeğinin ilk faktör analizinde varimax döndürme işlemi sonucunda, özdeğeri 1.00'dan büyük olan ölçeğe ilişkin açıkladıkları varyans \% 59.629 olan 14 faktör ortaya çıkmıştır. Varimax döndürme ile birlikte yapılan Anti-image Correlation işlemi sonucunda ise $35,51,34,4,50,49,22,14,56,44,31,58,55,17$ ve 46 . maddeler farklı faktörlere yakın yük verdiği için ölçekten çıkarılmıştır. $\mathrm{Bu}$ işlem için bir madde herhangi iki faktörde aynı anda bulunuyorsa ve aralarında .10'dan az fark varsa madde ölçekten çıkartılır (Büyüköztürk, 2012) görüşü benimsenmiştir. İkinci döndürmede KMO katsayısı .921 bulunmuş, özdeğeri 1.00'dan büyük olan ve ölçeğe ilişkin açıkladıkları varyans \% 58.018 olan 11 faktör ortaya çıkmıştır. Bu aşamada, 43, 18, 19 ve 13 . maddeler farklı faktöre yakın yük verdiği için ölçekten çıkartılmıştır. Üçüncü döndürmede KMO katsayıs1 .918 olarak çıkmıştır. Döndürme sonucunda, özdeğeri 1.00'dan büyük olan ve ölçeğe ilişkin açıkladıkları varyans \% 59.226 olan 11 faktör ortaya çıkmıştır. Bu işlem sonucunda, 47, 41, 29, 16, 28, 30. maddeler diğer faktörlere yakın yük verdiği için ölçekten çıkartılmıştır. Dördüncü döndürme işlemi sonucunda KMO katsayısı .918 olarak çıkmıştır. Döndürme işlemi sonucunda, özdeğeri 1.00'dan büyük olan ve ölçeğe ilişkin açıkladıkları toplam varyans \% 55.028 olan 8 faktör ortaya çıkmıştır. Analizler sonucunda birinci faktörde: 38, 39, 36, 37, 48, 45, 2, 12, 7, 6. maddeler, ikinci faktörde: 62, 61, 54, 53, 52. maddeler, üçüncü faktörde: 25, 24, 26, 21, 23. maddeler, dördüncü faktörde: 10, 11, 59, 42. maddeler, beşinci faktörde: 40, 57, 15, 60. maddeler, altıncı faktörde: 8, 9, 27. maddeler, yedinci faktörde: 32, 33, 20. maddeler, sekizinci faktörde: 1, 5, 3. maddeler yer almaktadır.

Son olarak özel/üstün yetenekli ön ergenlik döneminde olan ortaokul öğrencileri için sosyal beceri ölçeğinde maddeler birden otuz yediye kadar sırasıyla yeniden numaralandırılarak otuz yedi madde üzerinden tekrar faktör analizi yapılmıştır. 37 maddelik özel/üstün yetenekli ortaokul öğrencileri için sosyal beceri ölçeğinin faktör analizi sonucunda elde edilen faktör yüklerine ait özdeğerleri, faktörlerin açıkladıkları varyanslar ve açıklanan toplam varyanslar Tablo 3'de gösterilmiştir. 
Tablo 3. Özel/Üstün Yetenekli Ortaokul Öğrencileri İçin Sosyal Beceri Ölçeğine Ait Özdeğerler ve Açıklanan Varyans Yüzdeleri

\begin{tabular}{lccc}
\hline Faktörler & Özdeğerler & $\begin{array}{c}\text { Açıklanan Varyans } \\
\text { Yüzdesi }\end{array}$ & $\begin{array}{c}\text { Açıklanan Toplam } \\
\text { Varyans Yüzdesi }\end{array}$ \\
\hline Faktör 1 & 9.79 & 14.22 & 14.22 \\
Faktör 2 & 2.72 & 6.99 & 21.22 \\
Faktör 3 & 1.69 & 6.99 & 28.21 \\
Faktör 4 & 1.41 & 6.60 & 34.81 \\
Faktör 5 & 1.37 & 5.79 & 40.60 \\
Faktör 6 & 1.26 & 5.49 & 46.09 \\
Faktör 7 & 1.08 & 4.85 & 50.94 \\
Faktör 8 & 1.04 & 4.09 & 55.03 \\
\hline
\end{tabular}

Tablo 3 incelendiğinde ölçekteki 37 maddenin özdeğeri 1'den büyük olan sekiz faktör altında toplandığı görülmektedir. Bu sekiz faktörün birlikte ölçeğe ilişkin açıkladıkları varyans \% 55.03'dür. Birinci faktör ile ölçeğe ilişkin varyansın \% 14.22'i; ikinci faktör ile ölçeğe ilişkin varyansın \%6.99'u, üçüncü faktör ile ölçeğe ilişkin varyansın \%6.99'u, dördüncü faktör ile ölçeğe ilişkin varyansın \%6.60'1, beşinci faktör ile ölçeğe ilişkin varyansın \%5.79'u, altıncı faktör ile ölçeğe ilişkin varyansın \%5.49’u, yedinci faktör ile ölçeğe ilişkin varyansın \%4.85'i, sekizinci faktör ile ölçeğe ilişkin varyansın \%4.09'u, açıklandığı söylenebilir. Etkili olan bu sekiz faktöre ait yükler Tablo 4'de gösterildiği gibi bulunmuştur.

Tablo 4'de ölçeğin sekiz faktörlü bir yapıda olduğu görülmesine karşın ilk faktörün özdeğeri 9.79 olarak bulunmuştur. Özdeğerlere göre çizilen Scree plot çizgi grafiğinde, birinci faktörden sonra yüksek ivmeli bir düşüş gözlenmektedir. Bu durum ölçeğin genel bir faktöre sahip olabileceğini göstermektedir (Büyüköztürk, 2012). Son haliyle ölçeğin birinci faktörü olan özgüven boyutunda sırasıyla; 1, 2, 3, 4, 5, 6, 7, 8, 9, 10. maddeler, ikinci faktörü olan duyarlılık boyutunda sırasıyla: 11, 12, 13, 14, 15. maddeler, üçüncü faktörü olan öz eleştiri yapabilme boyutunda sırasıyla; 16, 17, 18, 19 ve 20. maddeler, dördüncü faktörü olan sosyal kabul boyutunda sırasıyla; 21, 22, 23, 24. maddeler, beşinci faktörü olan güvengenlik boyutunda sirasıyla; 25, 26, 27, 28. maddeler, altınc1 faktörü olan nezaket kuralları boyutunda sirasıyla; 29, 30, 31. maddeler, yedinci faktörü olan mizah boyutunda sirasiyla, 32, 33, 34. maddeler ve sekizinci faktörü olan etkin dinleme boyutunda ise; 35, 36 ve 37. maddeler bulunmaktadır. 
Tablo 4. Nihai Özel/Üstün Yetenekli Ön Ergenlik Döneminde Olan Ortaokul Öğrencileri İçin Sosyal Beceri Ölçeğine Ait Faktör Yükleri

\begin{tabular}{|c|c|c|c|c|c|c|c|c|}
\hline No & Faktör 1 & Faktör 2 & Faktör 3 & Faktör 4 & Faktör 5 & Faktör 6 Faktör 7 & Faktör 8 & Toplam \\
\hline $1(38)$ & .80 & & & & & & & \\
\hline $2(39)$ & .78 & & & & & & & \\
\hline $3(36)$ & .73 & & & & & & & \\
\hline $4(37)$ & .69 & & & & & & & \\
\hline $5(48)$ & .67 & & & & & & & \\
\hline $6(45)$ & .66 & & & & & & & \\
\hline $7(2)$ & .63 & & & & & & & \\
\hline $8(12)$ & .58 & & & & & & & \\
\hline $9(7)$ & .53 & & & & & & & \\
\hline $10(6)$ & .48 & & & & & & & \\
\hline $11(62)$ & & .71 & & & & & & \\
\hline $12(61)$ & & .62 & & & & & & \\
\hline $13(54)$ & & .59 & & & & & & \\
\hline $14(53)$ & & .57 & & & & & & \\
\hline $15(52)$ & & .47 & & & & & & \\
\hline $16(25)$ & & & .68 & & & & & \\
\hline $17(24)$ & & & .67 & & & & & \\
\hline $18(26)$ & & & .64 & & & & & \\
\hline $19(21)$ & & & .52 & & & & & \\
\hline $20(23)$ & & & .50 & & & & & \\
\hline $21(10)$ & & & & .67 & & & & \\
\hline $22(11)$ & & & & .65 & & & & \\
\hline $23(59)$ & & & & .64 & & & & \\
\hline $24(42)$ & & & & .48 & & & & \\
\hline $25(40)$ & & & & & .62 & & & \\
\hline $26(57)$ & & & & & .59 & & & \\
\hline $27(15)$ & & & & & .55 & & & \\
\hline $28(60)$ & & & & & .53 & & & \\
\hline $29(8)$ & & & & & & .81 & & \\
\hline
\end{tabular}


30(9)

$31(27)$

32(32)

33(33)

34(20)

$35(1)$

36(5)

37(3)

Yüz.
.41

.69

.64

.60

* Parantez içerisinde yer alan sayılar ilk ölçek uygulama formundaki madde numaralarıdır.

\section{Doğrulayıcı Faktör Analizi (DFA)}

Özel/üstün yetenekli ön ergenlik döneminde olan ortaokul öğrencileri için geliştirilen ölçeğin 37 madde ve sekiz boyut olan asıl formunun veri setinin doğrulayıcı faktör analizine uygunluğu incelenmiş ve uç değer gösteren 10 veri, veri setinden çıkarılmıştır. Özel/Üstün Yetenekli Ön Ergenlik Döneminde Olan Ortaokul Öğrencileri İçin Sosyal Beceri Ölçeğinin hesaplanan t değerleri Şekil 1'de verilmiştir.

Şekil 1 incelendiğinde, sadece 37. madde dışındaki bütün maddelerdeki $t$ değerlerinin 2.89-9.85 arasında .01 düzeyinde anlamlı olduğu görülmektedir. 37. maddenin t değeri ise 1.73 olarak bulunmuştur. Bu değer her ne kadar 1.96 değerinden küçük olsa da ölçeğin faktör yapısını bozmamak için bu madde ölçekten çıkarılmamıştır. Ölçeğin sekiz boyutlu modeli için gizil değişkenlerin gözlenen değişkeni açıklama oranlarının anlamlılık düzeyi parametre tahminleri t değerleri 1.96'yı aşarsa .05 düzeyinde ve 2.26'yı aşarsa .01 düzeyinde (Çokluk, Şekercioğlu ve Büyüköztürk, 2010) anlamlı olacağı belirtildiğinden bulunan değerler genelde .01 düzeyinde anlamlı bulunmuştur. 


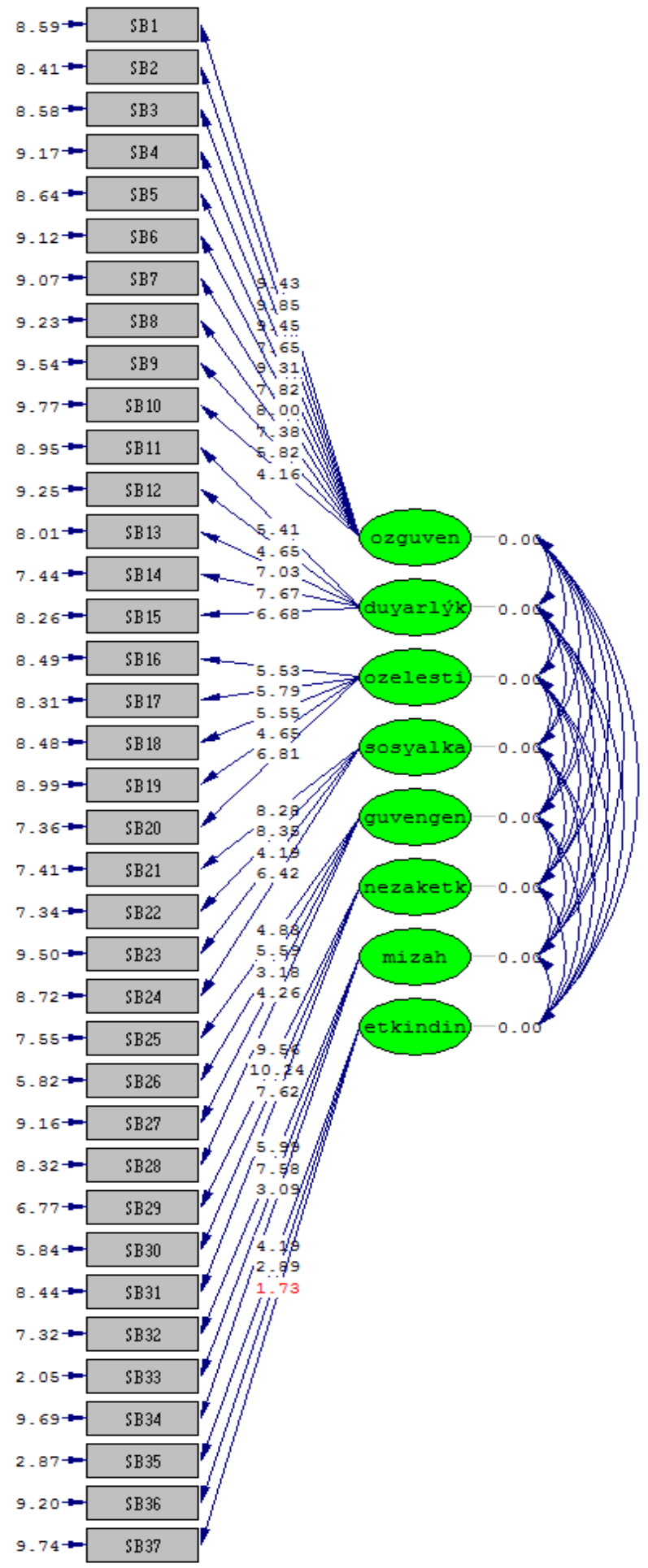

Şekil 1. Özel/üstün yetenekli ön ergenlik dönemindeki ortaokul öğrencileri için sosyal beceri ölçeği sekiz boyutlu modeli için t değerleri

Özel/Üstün Yetenekli Ön Ergenlik Döneminde Olan Ortaokul Öğrencileri İçin Sosyal Beceri Ölçeğinin path katsayıları ve hata varyansları incelenmiş ve sonuçlar Şekil 2'de gösterilmiştir. 


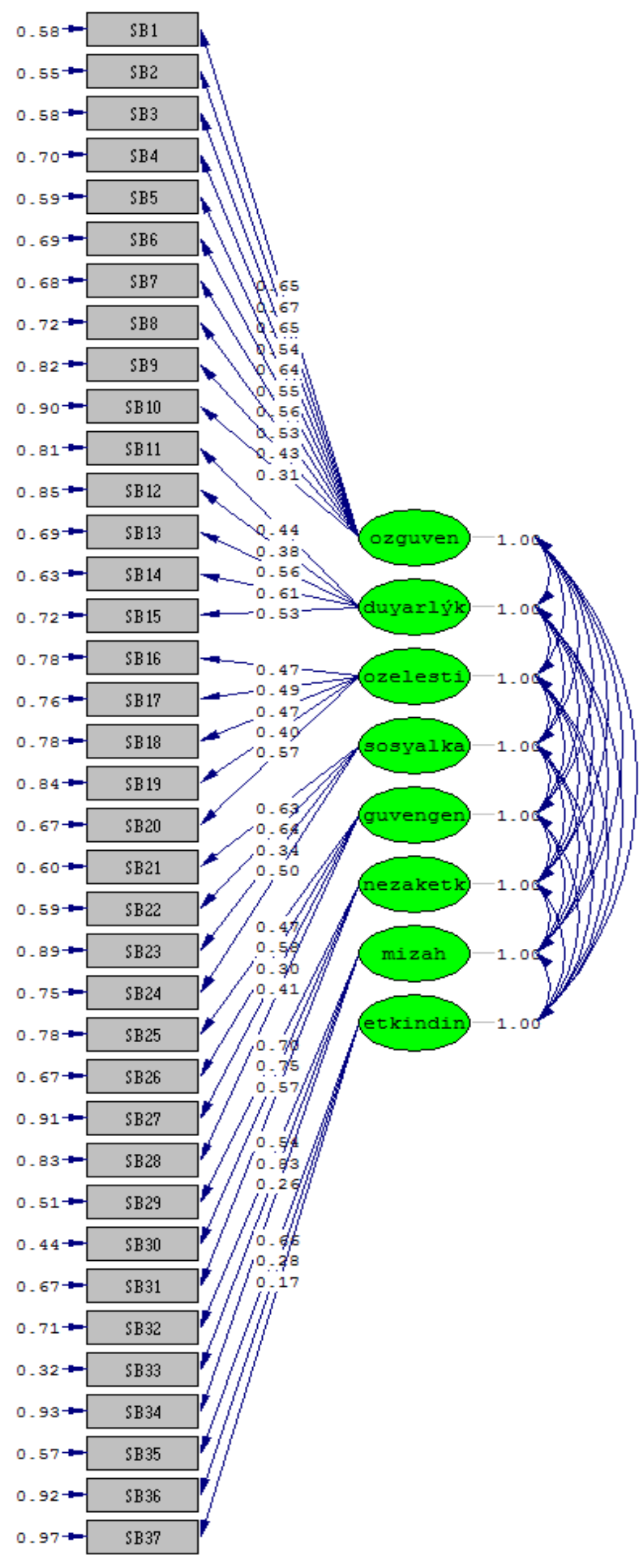

Chi-Square $=871.17, \mathrm{df}=601, \mathrm{P}-\mathrm{value}=0.00000, \mathrm{RMSEA}=0.048$

Şekil 2. Özel/üstün yetenekli ön ergenlik dönemindeki ortaokul öğrencileri için sosyal beceri ölçeğinin path katsayıları 
Şekil 2'de Özel/Üstün Yetenekli Ön Ergenlik Dönemindeki Ortaokul Öğrencileri İçin Sosyal Beceri Ölçeğinin path katsayılarının özgüven alt boyutu için .31 ile .67 arasında; duyarlılık alt boyutu için .44 ile .61, özeleştiri alt boyutu için .47-.57 arasında, sosyal kabul alt boyutu için .34-.63 arasında, güvengenlik alt boyutu için .30-.58 arasında, nezaket kuralları alt boyutu için .57-.75 arasında, mizah alt boyutu için .26-.84 arasında, etkin dinleme alt boyutu için .17-.66 olduğu görülmektedir. Modelin uyum indeksleri incelenmiş ve sonuçlar Tablo 5'de sunulmuştur.

Tablo 5. Özel/Üstün Yetenekli Ön Ergenlik Dönemindeki Ortaokul Öğrencileri İçin Sosyal Beceri Ölçeğinin Uyum İndeksleri

\begin{tabular}{lllllllllll}
\hline $\mathrm{X} 2$ & $\begin{array}{l}\mathrm{X} 2 / \mathrm{d} \\
\mathrm{f}\end{array}$ & $\mathrm{p}$ & NFI & NNFI & CFI & GFI & AGFI & SRMR & IFI & RMSEA \\
& & & & & & & & & \\
\hline 871.17 & 1.45 & .000 & .71 & .86 & .87 & .81 & .78 & .076 & .88 & .048 \\
\hline
\end{tabular}

Tablo 5 incelendiğinde ki kare değeri $(\mathrm{x} 2=871.17, \mathrm{n}=200, \mathrm{sd}=601, \mathrm{p}=.000)$ anlaml bulunmuştur. Ki kare değeri/serbestlik derecesi oranı 1.45 olarak bulunmuştur. Büyük örneklemlerde bu oranın 3'ün altında olması mükemmel uyuma işaret etmektedir (Kline, 2005; Sümer, 2000; Akt. Çokluk ve diğerleri, 2010). RMSEA değeri .048 olarak bulunmuştur. $\mathrm{Bu}$ değer .08 'den küçük olduğundan iyi uyum göstergesi olarak değerlendirilmektedir (Jöreskog ve Sörbom, 1993; Akt. Çokluk ve diğerleri, 2010). Diğer değerler incelendiğinde; GFI .81, ve AGFI .78 olarak bulunmuştur. Standardize edilmiş RMR uyum değeri .076 olarak bulunmuştur. $\mathrm{Bu}$ değer .08'in altında ise iyi uyumu göstermektedir (Brown, 2006; Akt. Çokluk ve diğerleri, 2010). CFI ve NNFI uyum değerleri ise sırasıyla .87 ve .86 olarak bulunmuştur. Bu değerler iyi uyumu göstermektedir (Sümer, 2000; Akt. Çokluk ve diğerleri, 2010). Bu sonuçlara göre elde edilen uyum değerleri modelin iyi uyum verdiğini göstermektedir.

\section{Benzer Ölçekler Geçerliği}

Özel/üstün yetenekli ön ergenlik dönemindeki ortaokul öğrencileri için Sosyal Beceri Ölçeğinin benzer ölçekler geçerliği KA-Si Ergenler için Empatik Eğilim Ölçeği ile toplam puanlar üzerinden yapılmış, korelasyon analizi sonucunda Pearson Momentler Çarpımı Korelasyon katsayısı .67 olarak $\mathrm{p}<.001$ düzeyinde anlamlı bulunmuştur. 


\section{Güvenirliğe İlişkin Bulgular}

\section{Özel/Üstün Yetenekli Ön Ergenlik Döneminde Olan Ortaokul Öğrencileri İçin Sosyal Beceri Ölçeğinin Güvenirliğine İlişsin Bulgular}

Madde Toplam Puan Korelasyonu

Madde toplam puan korelasyonu ile alt ve üst \%27 grupların madde puanlarının karşılaştırılmasına ilişkin korelasyon değerleri ve t testine ilişkin sonuçlar Tablo 6'da gösterilmiştir.

Tablo 6. Madde Toplam Korelasyonu Ile Alt ve Üst \%27 Gruplarının Madde Puanlarının Karşılaştırılmasına İlişkin Korelasyon Değerleri ve t Testine İlişkin Sonuçlar

Düzeltilmiş Madde Toplam t

Madde Korelasyonları a

\begin{tabular}{lcc} 
& & (Alt \%27-Üst \%27)b \\
\hline $1(38)$ & .59 & $15.52^{* *}$ \\
$2(39)$ & .65 & $17.68^{* *}$ \\
$3(36)$ & .64 & $17.92^{* *}$ \\
$4(37)$ & .55 & $15.28^{* *}$ \\
$5(48)$ & .53 & $12.44^{* *}$ \\
$6(45)$ & .53 & $10.97^{* *}$ \\
$7(2)$ & .58 & $14.52^{* *}$ \\
$8(12)$ & .61 & $15.08^{* *}$ \\
$9(7)$ & .42 & $8.73^{* *}$ \\
$10(6)$ & .45 & $9.89^{* *}$ \\
$11(62)$ & .47 & $10.45^{* *}$ \\
$12(61)$ & .52 & $11.38^{* *}$ \\
$13(54)$ & .55 & $11.19^{* *}$ \\
$14(53)$ & .50 & $12.15^{* *}$ \\
$15(22)$ & .56 & $13.30^{* *}$ \\
$16(25)$ & .44 & $10.86^{* *}$ \\
$17(24)$ & .37 & $9.44^{* *}$ \\
$18(26)$ & .32 & $8.49^{* *}$ \\
$19(21)$ & .48 & $11.28^{* *}$ \\
$20(23)$ & .51 & $12.59^{* *}$ \\
& &
\end{tabular}




\begin{tabular}{|c|c|c|}
\hline $21(10)$ & .46 & $10.36^{* *}$ \\
\hline $22(11)$ & .50 & $9.38 * *$ \\
\hline 23(59) & .35 & $6.75^{* *}$ \\
\hline $24(42)$ & .47 & $8.92 * *$ \\
\hline $25(40)$ & .44 & $11.95^{* *}$ \\
\hline $26(57)$ & .46 & $10.48 * *$ \\
\hline $27(15)$ & .26 & $6.61 * *$ \\
\hline $28(60)$ & .38 & $9.69 * *$ \\
\hline $29(8)$ & .37 & $6.89 * *$ \\
\hline $30(9)$ & .37 & $6.78 * *$ \\
\hline $31(27)$ & .52 & $10.73 * *$ \\
\hline $32(32)$ & .38 & $7.66^{* * *}$ \\
\hline $33(33)$ & .45 & $10.86^{* *}$ \\
\hline $34(20)$ & .29 & $6.68 * *$ \\
\hline $35(1)$ & .44 & $11.87 * *$ \\
\hline $36(5)$ & .41 & $8.43 * *$ \\
\hline $37(3)$ & .42 & $10.32 * *$ \\
\hline
\end{tabular}

Tablo 6 incelendiğinde, özel/üstün yetenekli ön ergenlik dönemindeki ortaokul öğrencileri için sosyal beceri ölçeğinin düzeltilmiş madde-toplam korelasyonları .32 ile .65 arasında değişmektedir. Madde toplam korelasyonu .30 ve daha yüksek olan maddelerin bireyleri iyi derecede ayırt ettiği söylenebilir (Büyüköztürk, 2012). Ayrıca, \%27'lik alt ve üst grupların madde puanlarındaki farklara ilişkin $t(\mathrm{sd}=216)$ değerlerinin ise 6.61 ile 17.92 arasında değiştiği ve elde edilen $\mathrm{t}$ değerlerinin .001 düzeyinde anlamlı olduğu görülmektedir. $\mathrm{Bu}$ değerler ölçekteki maddelerin geçerliklerinin yüksek olduğunu, yöntemsel yeterlik bakımından ayırt etmeye ve aynı davranışı ölçmeye yönelik maddeler olduklarını göstermektedir (Büyüköztürk, 2012).

Alt Ölçekler ve Toplam Puan Arasındaki Korelasyon Katsayıları

Ölçeğin madde sayılarına, faktör puanlarının ortalama ve standart sapmalarına ve faktör puanlarına ait hesaplanan ikili korelasyonlar hesaplanmış sonuçlar Tablo 7'de gösterilmiştir. 
Tablo 7. Ölçeğe Ait Betimsel İstatistikler ve Alt Ölçekler İle Toplam Puan Arasındaki Korelasyon Katsayıları

\begin{tabular}{lccccccccc}
\hline Faktör & 1 & 2 & 3 & 4 & 5 & 6 & 7 & 8 & Toplam \\
\hline 1 & 1 & $.52^{* *}$ & $.37^{* *}$ & $.38^{* *}$ & $.48^{* *}$ & $.34^{* *}$ & $.45^{* *}$ & $.48^{* *}$ & $.85^{* *}$ \\
2 & & 1 & $.47^{* *}$ & $.55^{* *}$ & $.39^{* *}$ & $.48^{* *}$ & $.38^{* *}$ & $.45^{* *}$ & $.77^{* *}$ \\
3 & & & 1 & $.49^{* *}$ & $.39^{* *}$ & $.42^{* *}$ & $.28^{* *}$ & $.40^{* *}$ & $.68^{* *}$ \\
4 & & & & 1 & $.27^{* *}$ & $.51^{* *}$ & $.35^{* *}$ & $.45^{* *}$ & $.66^{* *}$ \\
5 & & & & & 1 & $.25^{* *}$ & $.32^{* *}$ & $.35^{* *}$ & $.63^{* *}$ \\
6 & & & & & & 1 & $.16^{* *}$ & $.43^{* *}$ & $.58^{* *}$ \\
7 & & & & & & & 1 & $.32^{* *}$ & $.57^{* *}$ \\
8 & & & & & & & & 1 & $.65^{* *}$ \\
Toplam & & & & & & & & & 1 \\
SBÖ & & & & & & & & & \\
$\mathrm{X}$ & 31.83 & 16.99 & 16.08 & 14.56 & 13.58 & 11.12 & 10.54 & 10.37 & 125.06 \\
$\mathrm{~S}$ & 6.14 & 2.76 & 2.89 & 1.80 & 2.14 & 1.37 & 1.57 & 1.46 & 14.44 \\
\hline * $\mathrm{p}<.001, \mathrm{n}=406$ & & & & & & & &
\end{tabular}

Tablo 7’de görüldüğü gibi özel/üstün yetenekli ön ergenlik döneminde olan ortaokul öğrencileri için geliştirilen sosyal beceri ölçeğinin tüm alt ölçeklerinin birbirleri ile ve toplamla ilişkileri $\mathrm{p}<.001$ düzeyinde yüksek derecede ve pozitif yönde anlamlı bulunmuştur. $\mathrm{Bu}$ da alt ölçeklerin birbirleri ile uyumlu olduğunu göstermektedir.

Cronbach Alpha İç Tutarlık Analizi

Ölçek 406 kişiye uygulanmış ölçeğin iç tutarlık analizi için Cronbach Alpha iç tutarlık katsayılarına bakılmış sonuçlar Tablo 8'de gösterilmiştir.

Tablo 8 incelendiğinde ölçeğin tamamı için Cronbach Alpha iç tutarlık katsayısının .92 olduğu görülmektedir. Alt faktörler için Cronbach Alpha değerleri özgüven için; .89, duyarlılık için; .77, öz-eleştiri yapabilme için; .72, sosyal kabul için; .70, güvengenlik için; .63 , nezaket kuralları için; .70, mizah için, .62, etkin dinleme için ise .61 olarak bulunmuştur.

İki Yarl Test Güvenirliği

Test yarılama tekniği ile hesaplanan güvenirlik katsayısı Spearman-Brown düzeltmesiyle birinci ve ikinci yarılar için .84 bulunmuştur. 
Tablo 8. Ölçeğe Ait Cronbach Alpha İç Tutarlık Analizi Sonuçları

\begin{tabular}{ll}
\hline Faktörler & Cronbach Alpha Değeri \\
\hline Özgüven & .89 \\
Duyarlılık & .77 \\
Öz-Eleştiri Yapabilme & .72 \\
Sosyal Kabul & .70 \\
Güvengenlik & .63 \\
Nezaket Kuralları & .70 \\
Mizah & .62 \\
Etkin Dinleme & .61 \\
Toplam SBÖ Puanı & .92 \\
\hline
\end{tabular}

\section{Tartışma}

Bu çalışmada özel/üstün yetenekli ön ergenlik döneminde bulunan ortaokul öğrencileri için kullanılabilecek bir sosyal beceri ölçeği geliştirmek amaçlanmıştır. Çalışmada özel/üstün yetenekli ön ergenlik döneminde bulunan ortaokul öğrencileri için Türkiye örnekleminde kullanılabilecek bir sosyal beceri ölçeği geliştirilmiş ve bu ölçeğin yapı geçerliği açımlayıcı ve doğrulayıcı faktör analizleri kullanılarak yapılmıştır. Sonuçlar ölçeğin sekiz faktörlü bir yapıda olduğu ortaya koymuştur. Sırası ile özgüven, duyarlılık, öz-eleştiri yapabilme, sosyal kabul, güvengenlik, nezaket kuralları, mizah ve etkin dinleme olarak adlandırılan bu sekiz faktörün birlikte ölçeğe ilişkin açıkladıkları varyans \% 55.03'dir. Özgüven alt boyutu ile ölçeğe ilişkin varyansın \%14.22'si; duyarlılık alt boyutu ile ölçeğe ilişkin varyansın \%6.99'u; öz-eleştiri yapabilme alt boyutu ile ölçeğe ilişkin varyansın \%6.99'u; sosyal kabul alt boyutu ile ölçeğe ilişkin varyansın \%6.60'1; güvengenlik alt boyutu ile ölçeğe ilişkin varyansın \%5.79'u; nezaket kuralları alt boyutu ile ölçeğe ilişkin varyansın \%5.49'u; mizah alt boyutu ile ölçeğe ilişkin varyansın $\% 4.85$ 'i; etkin dinleme alt boyutu ile ölçeğe ilişkin varyansın \%4.09'unun, açıklandığı görülmektedir. Uygulanan doğrulayıcı faktör analizi sonuçlarına göre, ölçeğin uyum değerleri $X^{2}=871.17, X^{2} / d f=1.45, p<.000, \quad N F I=.71$, $\mathrm{NNFI}=.86, \mathrm{CFI}=.87, \mathrm{GFI}=.81, \mathrm{AGFI}=.78, \mathrm{RMR}=.050, \mathrm{SRMR}=.076, \mathrm{IFI}=.88, \mathrm{RMSEA}=.048$ olarak bulunmuştur. Elde edilen sonuçlar ölçeğin iyi uyum verdiğini göstermektedir (Brown, 2006; Hooper, Caughlan ve Mullen, 2008; Jöreskog ve Sörbom, 1993; Kline, 2005; Sümer, 2000; Akt. Çokluk ve diğerleri, 2010). Bulgular sosyal beceri ölçeğinin özel/üstün yetenekli ortaokul öğrencilerinde kullanılabileceğini göstermektedir. 
Ölçeğin hazırlanma aşamasında çeşitli odak grup görüşmeleri yapılmasının, alan yazındaki kuramsal çerçevenin titizlikle taranmasının ayrıca ölçek maddelerinin kuramsal yapıya uygun hazırlanmasının ölçeğin özel/üstün yetenekli ön ergenlik dönemindeki ortaokul öğrencilerinde kullanılabilecek geçerli ve güvenilir bir ölçek olmasını sağladığı söylenebilir. Ölçeğe açımlayıcı faktör analizi yapıldıktan sonra doğrulayıcı faktör analizi yapılması ölçeğin geçerliğinin güçlü olmasının da bir kanıtı olarak gösterilebilir. Modelin uyum değerleri incelendiğinde modelin iyi uyum verdiği görülmektedir.

Özel/üstün yetenekli ortaokul öğrencileri için Sosyal Beceri Ölçeğinin benzer ölçekler geçerliği KA-Si Ergenler için Empatik Eğilim Ölçeği ile yapılmış, iki ölçeğin Pearson Momentler Çarpımı Korelasyon katsayısı .67 olarak $\mathrm{p}<.001$ düzeyinde anlamlı bulunmuştur. $\mathrm{Bu}$ da iki ölçeğin benzer yapıda olduğunu göstermektedir.

Ölçek için yapılan güvenirlik analizlerinde madde toplam puan ve alt üst \%27 karşılaştırmasında ölçekte bulunan maddelerin geçerliklerinin yüksek düzeyde olduğu, yöntemsel yeterlik açısından ayırt edici ve aynı davranışı ölçebildikleri ortaya konulmuştur. Alt ölçeklerin birbiri ile ve toplam puanla arasındaki ilişkiler anlamlı bulunmuştur. Ayrıca yapılan iç tutarlık analizinde ölçeğin tamamı için Cronbach Alpha iç tutarlık katsayısı .92 olarak bulunmuştur. Alt faktörler için yapılan Cronbach Alpha iç tutarlık analizinde Cronbach Alpha değerleri alt faktörler için sırasıyla; .89, .77, .72, .70, .63, .70, .62, .61 olarak bulunmuştur. Test yarılama tekniği ile hesaplanan güvenirlik katsayısı ise SpearmanBrown düzeltmesiyle birinci ve ikinci yarılar için .84 olarak bulunmuştur.

$\mathrm{Bu}$ geçerlik ve güvenirlik sonuçları göz önüne alındığında ölçeğin özel/üstün yetenekli ortaokul öğrencilerinde kullanılabilecek geçerli ve güvenilir bir ölçme aracı (Ek.1) olduğu söylenebilir.

\section{Sonuç}

Sonuç olarak; bu çalışmada Türkiye örnekleminde kullanılabilecek özel/üstün yetenekli ön ergenlik dönemindeki ortaokul öğrencileri için geçerli ve güvenilir bir sosyal beceri ölçeği geliştirilmiştir. Özel/üstün yetenekli ön ergenlik dönemindeki ortaokul öğrencileri için geliştirilen sosyal beceri ölçeği sekiz faktörlü bir ölçektir. Ölçek alt boyutları ile kullanılabileceği gibi ölçekten toplam puan da alınabilir. Ölçekte ters puanlanan madde olmayıp ölçekten en düşük 37, en yüksek 148 puan alınabilir. Ölçekten alınan puanlar arttıkça öğrencilerin sosyal beceri düzeyleri artmaktadır.

$\mathrm{Bu}$ çalışmanın sonuçlarına göre bazı öneriler sıralanabilir: Çalışmada özel/üstün yetenekli ön ergenlik dönemindeki ortaokul öğrencileri ile çalışılmıştır. Alan yazında 
özel/üstün yetenekli ilkokul ve lise öğrencileri için de sosyal beceri ölçeği bulunmadığı görüldüğünden bu yaş grupları ile de ölçek geliştirme çalışmalarının yaygınlaştırılması sağlanabilir. Ayrıca BİLSEM'lere devam eden öğrencilere yönelik sosyal beceri eğitimleri artırılabilir ve bu eğitimlerde geliştirilen sosyal beceri ölçeği kullanılabilir.

$\mathrm{Bu}$ çalışmanın bazı sınırlılıkları şunlardır; çalışmada Türkiye genelindeki çalışmaya katılmaya gönüllü Bilim ve Sanat Merkezleri ve merkezlerde eğitim gören çalışmaya katılmaya istekli ortaokul öğrencileri alınmıştır. Dolayısı ile bu çalışma bu öğrencilerden elde edilen verilerle sınırlandırılmıştır. Ayrıca çalışmanın bazı verileri araştırmacılar tarafindan değil Türkiye'de farklı illerdeki BİLSEM'lere ölçekler kargo ile gönderilerek toplanmıştır. Bu da çalışmanın bir diğer sınırlılığıdır.

Etik Kurul İzin Bilgisi: Çalış̧a için 13.05.2020 tarihinde Burdur Mehmet Akif Ersoy Üniversitesi Girişimsel Olmayan Klinik Araştırmalar Etik Kurulundan GO 2020/130 karar sayılı etik kurul onayı alınmıştır. 


\section{Kaynakça}

Akkan, H. (2012). Üstün zekalı 6-8. sinıf öğrencilerinin iki farkl akademik ortamdaki sosyometrik statülerine göre empatik eğilimleri, yaşam doyumları ve aile yaşantıları. Yayımlanmamış yüksek lisans tezi, Dokuz Eylül Üniversitesi, İzmir.

Akkök, F. (1999). İlköğretimde sosyal becerilerin geliştirilmesi anne-baba el kitabı. İstanbul: Özgür Yayınları.

Anme T., Shinohara R., Sugisawa Y., Tanaka E., Watanabe T., \& Hoshino T. (2013). Validity and reliability of the social skill scale (SSS) as an index of social competence for preschool children. Journal of Health Science, 3(1), 5-11.

Avcıoğlu, H. (2007). Sosyal becerileri değerlendirme ölçeğinin geçerlik ve güvenirlik çalışması (4-6 Yaş). AIBB̈̈, Eğitim Fakültesi Dergisi, 7(2), 87-101.

Bacanlı, H. (1999). Sosyal beceri eğitimi. İçinde Y. Kuzgun (Ed.) İlköğretimde rehberlik (s. 171-188.). Ankara: Nobel Yayın Dağıtım.

Bilgiç, N., Taştan, A., Kurukaya, G., Kaya, K., Avanoğlu, O. ve Topal, T. (2013). Özel yetenekli bireylerin eğitimi strateji ve uygulama kllavuzu. Ankara: Milli Eğitim Bakanlığı Özel Eğitim ve Rehberlik Hizmetleri Genel Müdürlüğü.

Büyüköztürk, Ş. (2012). Sosyal bilimler için veri analizi el kitabı. İstatistik, araştırma deseni SPSS uygulamalarl ve yorum. (17. Baskı) Ankara: Pegem Akademi.

Büyüköztürk, Ş., Kılıç Çakmak, E., Akgün, Ö. E., Karadeniz, Ş. ve Demirel, F. (2016). Bilimsel araştırma yöntemleri. Ankara: Pegem Akademi.

Cross, J. R., \& Cross, T. L. (2015). Clinical and mental health issues in counseling the gifted individual. Journal of Counseling and Development, 93(2), 163-172.

Çokluk, Ö, Şekercioğlu, G. ve Büyüköztürk, Ş. (2010). Sosyal Bilimler için çok değişkenli istatistik. SPSS ve LISREL uygulamalart. Ankara: Pegem Akademi.

Elksnin L.K., \& Elksnin, N. (1995), Assessment and instruction of social skills. San Diego CA: Singular Publishing Group.

Eyre, D. (1999) Ten years of provision for the gifted and talented in Oxfordshire ordinary schools: insights into policy and practice. Gifted and Talented International, 14, 12- 

20

Freeman, J. (2001) Out-of-school educational provision for the gifted and talented around the world. A report for the DfES. http://www.joanfreeman.com/mainpages/freepapers.htm.

Gagné, F. (1995) From giftedness to talent: A developmental model and its impact on the language of the field. Roeper Review, 18(2), 103-111.

Gresham, F. M, \& Elliot, S. N. (2008). SSIS Social skills improvement system: rating scales manual. Minneapolis: Pearson.

Gresham, F. M., \& Elliott, S. N. (1990). Social skills rating system manual. Circle Pines, MN: American Guidance Service.

Hallahan, D. P., \& Kauffman, J. M. (2003). Exceptional learners: Introduction to special education. Boston: Allyn and Bacon.

Karataş, Z., Sağ, R., \& Arslan, D. (2015). Development of social skill rating scale for primary school students-teacher form (SSRS-T) and analysis of its psychometric properties. Procedia - Social and Behavioral Sciences, 197, 1447-1453.

Kaya, A. ve Siyez, D. M. (2010). KA-Sİ Çocuk ve ergenler için empatik eğilim ölçeği: geliştirilmesi geçerlik ve güvenirlik çalışması. Eğitim ve Bilim, 35(156), 110-125.

Matson, J. L., Rotatori, A. F., \& Helsel, W. J. (1983). Development of a rating scale to measure social skills in children: The matson evaluation of social skills with youngsters (MESSY). Behaviour Research and Therapy, 21(4), 335-340.

Merrell, K. W. (2002). School social behavior scales, (2th ed.). Eugene, OR:

Assessment-Intervention Resources.

MEB (2018). Özel ĕgitim hizmetleri yönetmeliği. Say1: 30471.

Ömeroğlu, E., Büyüköztürk, Ş., Aydoğan, Y., Çakan, M., Kılıç Çakmak, E., Özyürek, A.

ve diğerleri. (2014). (2014). Okul öncesi sosyal beceri değerlendirme ölçeği öğretmen formunun geliştirilmesi: Geçerlik ve güvenirlik analizleri. 21. Yüzyılda Eğitim ve Toplum, 3(8), 37-46.

Riggio, R.E. (1986) The assessment of basic social skills. Journal of Personality and 
Social Psychology, 51(3),649-660.

Samanc1, O. ve Diş, O. (2014). Sosyal becerileri zayıf olan ilkokul öğrencilerinin tutum ve davranışlarının öğretmen görüşlerine göre değerlendirilmesi. Kastamonu Eğitim Dergisi, 22(2), 573-590.

Seven, S. (2008). Yedi-sekiz yaş çocuklarının sosyal becerilerinin incelenmesi. Fırat Üniversitesi Sosyal Bilimler Enstitüsü Dergisi, 18(2), 151-174.

Silverman, L. K. (2002). Asynchronous development. In M. Neihart, S. M. Reis, N. M. Robinson \& S. M. Moon (Eds.), The social and emotional development of gifted children: What do we know? (pp. 31-40). Waco, TX: Prufrock Press.

Steedly, K.M., Schwartz, A., Levin, M.A., \& Luke, S.D. (2008). Social skills and academic achievement. Evidence for Education, 3(2), 1-8.

Şahin, C. (2001). Sosyal beceri ve sosyal yeterlik. G. Ü. Kırşehir Ĕğitim Fakültesi Dergisi, 2(1), 9-19.

Tabachnick, B. G., \& Fidell, L.S. (2007). Using multivariate statistics (5th ed.). Needham Heights, MA: Allyn and Bacon Publishers.

Tagay, Ö., Baydan, Y. ve Voltan Acar, N. (2010). Sosyal beceri programının (blocks) ilköğretim ikinci kademe öğrencilerinin sosyal beceri düzeyleri üzerindeki etkisi. Mehmet Akif Üniversitesi Sosyal Bilimler Enstitüsü Dergisi, 2(3), 19-28.

Tawana, B.B.S., \& Moorc, K.A. (2011). What works for promoting and enhancing positive social skills: Lessons from experimental evaluations of programs and interventions. Child Trends, March, 1-12.

Uysal, A. ve Kaya-Balkan, İ. (2015) Sosyal beceri eğitimi alan ve almayan okul öncesi çocukların, sosyal beceri ve benlik kavramı düzeyleri açısından karşılaştırılması. Psikoloji Çalışmaları, 35(1), 27-56.

Yüksel, G. (1999). Sosyal beceri eğitiminin üniversite öğrencilerinin sosyal beceri düzeyine etkisi. Türk Psikolojik Danlşma ve Rehberlik Dergisi, 2(11),37-47. 


\section{Ek 1. Özel/Üstün Yetenekli Ön Ergenlik Dönemindeki Ortaokul Öğrencileri İçin Sosyal Beceri Ölçeği}

Yönerge: Değerli öğrenciler, aşağıda sizinle ilgili bazı cümleler sıralanmıştır. Lütfen her bir cümleyi okuyup bu ifadeleri ne sıklıkta gösterdiğinizi "hiç bir zaman (1)", "ara sıra (2)", "sık s1k

(3)", "her zaman (4)" seçeneklerinden en uygun olanı işaretleyerek belirtiniz. Teşekkür ederiz.

\begin{tabular}{|c|c|c|c|c|c|}
\hline & & 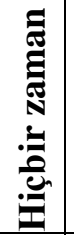 & 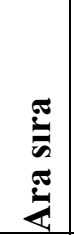 & $\begin{array}{l}\stackrel{y}{\bar{n}} \\
\frac{a}{\bar{n}}\end{array}$ & 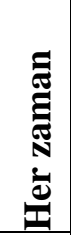 \\
\hline 1 & Yeni bir ortama girdiğimde tanımadığım kişilerle kolaylıkla tanışırım & & & & \\
\hline 2 & Yeni girdiğim bir ortama kolaylıkla uyum sağlarım & & & & \\
\hline 3 & $\begin{array}{l}\text { Tanımadığım ortamda düşüncelerimi ifade etmek konusunda kendime } \\
\text { güvenirim }\end{array}$ & & & & \\
\hline 4 & Topluluk önünde rahat konuşurum & & & & \\
\hline 5 & Yaşıtlarıma göre daha öz-güvenli biriyim & & & & \\
\hline 6 & Kolay arkadaş edinirim & & & & \\
\hline 7 & Düşüncelerimi kolaylıkla ifade ederim & & & & \\
\hline 8 & Çevremdekilerle kolaylıkla anlaşırım & & & & \\
\hline 9 & Benden büyük olsa bile başkalarıyla rahat iletişim kurarım & & & & \\
\hline 10 & Başkalarını kolaylıkla ikna ederim & & & & \\
\hline 11 & Olumsuz olaylara olumlu açıdan yaklaşırım & & & & \\
\hline 12 & Olaylara farklı açılardan bakarım & & & & \\
\hline 13 & Çevremdeki olaylara duyarlıyım & & & & \\
\hline 14 & Arkadaşlarımı olumlu davranmaya teşvik ederim & & & & \\
\hline 15 & Sorun çözümünde arkadaşlarıma ara buluculuk yaparım & & & & \\
\hline 16 & Gerektiğinde eleştirildiğim yönlerimi değiştiririm & & & & \\
\hline 17 & Eleştirilere açık biriyim & & & & \\
\hline 18 & Kendimi eleştiririm & & & & \\
\hline 19 & Arkadaşlarımla çalışırken hatalarımı görürüm & & & & \\
\hline 20 & Kendi yanlışlarımı açıkça ifade ederim & & & & \\
\hline 21 & Eşyalarımı gerektiğinde diğerleri ile paylaşırım & & & & \\
\hline 22 & Gerektiğinde arkadaşlarıma yardım ederim & & & & \\
\hline 23 & $\begin{array}{l}\text { Herkesi farklı özelliklerine (ırk, renk, dil, din, ekonomik durum, fiziksel } \\
\text { özellikler gibi) bakmaksızın olduğu gibi kabul ederim }\end{array}$ & & & & \\
\hline 24 & Arkadaşlarımın başarılarını takdir ederim & & & & \\
\hline 25 & Başkaları ile aynı fikirde olmadığımı söylerim & & & & \\
\hline 26 & Bana haksız davranıldığını düşündüğümde bunu uygun şekilde ifade ederim & & & & \\
\hline 27 & Kuralları gerektiğinde sorgularım & & & & \\
\hline 28 & Yaşıtlarıma göre daha olgun olduğumu düşünürüm & & & & \\
\hline 29 & Gerektiğinde teşekkür ederim & & & & \\
\hline 30 & Gerektiğinde özür dilerim & & & & \\
\hline 31 & Gerektiğinde günaydın, merhaba, iyi akşamlar derim & & & & \\
\hline 32 & Esprileri kolaylıkla anlarım & & & & \\
\hline 33 & Ortama uygun espriler yaparım & & & & \\
\hline 34 & Esprili ortamları severim & & & & \\
\hline 35 & Birisi ile konuşurken onu dikkatle dinlerim & & & & \\
\hline 36 & Konuşurken karşıdaki kişi ile kolaylıkla göz teması kurarım & & & & \\
\hline 37 & Karşımdaki kişinin beden dilinden duygularını anlarım & & & & \\
\hline
\end{tabular}

